\title{
Influence of Selected Factors on the Choice of Agriculture Subject among Secondary School Students in Uriri Sub-County, Kenya
}

\author{
Mr. Ongang'a P. O ${ }^{1}$, Dr. Nkurumwa A. $\mathrm{O}^{2}$ and Dr. Konyango J. J. O ${ }^{3}$ \\ ${ }^{1}$ (Department of Agricultural Education and Extension, Egerton University, Kenya) \\ ${ }^{2}$ (Department of Agricultural Education and Extension, Egerton University, Kenya) \\ 3 (Department of Agricultural Education and Extension, Egerton University, Kenya)
}

\begin{abstract}
In Kenya, subjects that students choose influence their careers a lot since the Ministry of Education (MOE) requires that secondary school students register for a minimum of seven and a maximum of nine subjects when they join form three. These subjects are grouped into various categories including; Sciences, Languages, Humanities, Technicals and Foreign languages. Agriculture is grouped among the many Technical subjects, which students only select one, despite its prospects in several careers like veterinary medicine, zoology, forestry and teaching among others. This situation of subject choice is the same in Uriri Sub-County where several technical subjects are offered. In the recent past, the number of students taking Agriculture has recorded an increase though it is not documented the key factors contributing to this. This study sought to explore the extent to which information on subject choice is received by Agriculture students. It also sought to determine the influence of career awareness and teaching methods on the choice to study Agriculture among secondary school students in Uriri Sub-County. The study employed ex-post facto research design. The target population in the study was 262 form three Agriculture students in Uriri Sub County. 152 Agriculture students were drawn by proportionate stratified random sampling. A closed ended questionnaire was used to collect data. Data collection was preceded by a pilot test whose analysis resulted in a reliability coefficient of 0.78 indicating that the instrument was reliable. Data was analysed using SPSS package version 22 and presented using frequencies, percentages, means and standard deviations. Inferential statistics (chi-square) was used test hypotheses at $\alpha=0.05$. The study found that there was sufficient subject choice information in schools. Career awareness was found to be high as well as influence of teaching methods. Career awareness did not have any statistically significant influence on the choice of Agriculture while Agriculture teaching methods was found to have statistically significant influence on the choice of Agriculture.
\end{abstract}

Key words: Agriculture subject, career awareness, secondary school students, subject choice, teaching methods

\section{Introduction}

Making choices is a vital part of life that is crowded with so many options. Education systems are characterised by several optional subjects that students have to choose from. The vocational education in other parts of the world, for example, the USA is characterised by students taking vocational courses with a substantially better understanding of general educational skills (Mustapha \& Greenan, 2007). In Malaysia, vocational education, hence technical subjects is meant to produce educated, skilled and motivated workforce. Technical and vocational education is considered as an important measure for development of workforce (Syeda, 2010). In Bangladesh, technical subjects are highly recognized due to their contribution to national development in areas of man-power creation and running of industries (Gazi, 2008).

In Africa, Agriculture subject has received an unfair treatment in that it has not been made compulsory, except in South Africa. In other countries like Nigeria, agriculture is an optional subject chosen alongside others like Islamic Religious Education (Ajidagba, 2010).

In Kenya, only three subjects are compulsory: Mathematics, English and Kiswahili, according to Kenya Institute of Education ([KIE], 2002). There are other twenty three subjects, Agriculture included, to choose from. A study by Ngesa (2006) revealed that among the optional subjects, Agriculture was ranked fifth in terms of popularity hence there is an increase in the number of students in the recent past (Kenya National Examinations Council [KNEC], 2013). The critical factor therefore is to link these chosen subjects with Joint Admissions Board (JAB) requirements since admission to Kenyan universities is pegged on cluster subjects for particular courses.

Subject choice therefore is an integral part of education systems beyond post-secondary. Appropriate choice of subjects is a vital step in achieving the educational goals of the syllabus (Ajidagba, 2010). According to Hughes and Mechur (2004), young people have high ambitions, expecting to be highly educated and have professional careers, yet research has shown that many do not develop coherent plans that can help them achieve 
their goals. Two thirds of high school graduates enter into tertiary institutions once they complete their studies to take courses they had chosen while at secondary school. Agriculture as a subject has been offered in Kenyan schools for decades. Just to mention, Uriri Sub-County is home to one of the earliest schools to offer Agriculture in Kenya: Rapogi High School. Others are Kisii, Narok, Njoro, Kangaru and Bungoma High Schools (Konyango, 2010).

Students in present schools experience a more complex schooling system characterised by many optional subjects. All these subjects are interconnected in one way or another with post-school and future life options. According to Atweh, Taylor and Singh (2005), the schooling years are meant to equip students with skills, knowledge and dispositions to meet their needs for the future citizenship and participation in economic life including employment and careers. Secondary schools must embrace the need to come up with guidelines that help students make informed choices concerning their future studies and work options during various stages of their educational journey.

Some of the possible contributors to choice of subjects are: school policy, parental guidance, peer influence, academic ability, intelligence, age, gender, ignorance and accidental choice (Owoyele \& Toyobo, 2008). The relative contribution of each factor could be constrained by aspects both within and outside the school, resulting in using subject choice as a tool for selecting, particularly for the less able students. Berry (2004) shows that the key factors that are the major contributors in student selection of subjects include: interest in the subject, perceived usefulness or importance of the subject, ability or success of the subject, career preference, subject combination for further studies, teachers' advice and the teaching strategy. Bordet (2002) looked at the learners' personality as an important determinant in subject and career choices and further argues that personality encompasses student's mental ability and attitude towards the subject. Mental ability, verbal comprehension, word fluency, numerical ability, reasoning ability and memory must be put in consideration when choosing subjects (Wagfield, Battle, Keller \& Eccles, 2002).

Teachers' role in subject choice is inevitable. If the teacher makes the subject enjoyable by use of appropriate teachings methods, students' interest is maintained (Walkington, 1998). A sound student-teacher relationship will help a great deal to build student's attitude towards Agriculture. This in the long run increases their likelihood of choosing the subject. A study by Ohiwerei and Nwosu (2009) revealed that a teacher is the central point of learning in the classroom situation because it is the methods and styles of teaching that create motivation to students. Inappropriate methods and styles of delivery will drive students away from the subject. Interest in the subject on the other hand is a contributor to performance.

Students have misconceptions of Agriculture work-related careers because not only are they unaware of the types of jobs there are in this sector but they also have the impression that all jobs in this area have very low pay (Chee \& Leong-Yong, 2011). The study by these scholars goes ahead to reveal that most parents will tell their children not to take careers in Agriculture because there is no future in this field. Improper linkage between trained skills and development needs is a major problem in Kenya. Career awareness is vital when individuals make choices of subjects because many students are not aware of the types of careers a particular subject prepares them for. There are many prospects in Agriculture such as veterinary medicine, farm management as well as teaching of Agriculture, which some students are not aware of. These mixed views called for an in-depth study of the influence of the two factors on choice of Agriculture. A fundamental issue here was to find out if students make choices on their own knowledge of the careers, or the Agriculture teachers play a major role through the various teaching methods employed.

Statement of the Problem

Agriculture is one of the key drivers of the Kenyan economy therefore the need to have people enter into Agriculture related careers. The subject is prominent based on the fact that it is endowed with many facilities and it is also manned by qualified teachers, therefore the number of students taking it is on the increase. The available literature is however inconclusive on the major factors contributing towards increased choice of Agriculture among secondary school students. This study therefore sought to determine the extent to which subject choice information is available for students, influence of career awareness and teaching methods on the choice of Agriculture subject among secondary school students in Uriri Sub-County.

\section{Methodology}

\section{Research Design}

The study adopted the ex-post facto research design. The design was more suitable for this study because the researcher sought to find out the subjects' already established opinions regarding the research objectives (Kombo \& Tromp, 2006). The study was conducted in Uriri Sub-County of Migori County. The SubCounty has an estimated student population of 1100 in form three. Out of this number, those taking Agriculture are estimated to be 262 .

Majority of people here are tobacco and sugarcane farmers, through which they are able to send their children to school. The Sub-County has twenty secondary schools. It also has various categories of schools i.e. 
mixed/co-educational schools and single gender schools, therefore making it suitable for the study. The population of this study composed of form three students in Uriri Sub-County, from which 262 form three Agriculture students were drawn.

The acceptable rule in determining sample size is to have a large sample as much as possible (Mugenda $\&$ Mugenda, 2003). There were about 262 form three Agriculture students. A table for determining sample size (Krejcie \& Morgan, 1970) was used to get 152 form three Agriculture students. Kathuri and Pals (1993) recommend a minimum sample of 100 respondents therefore a sample of 152 was appropriate to take care of attrition. Proportionate stratified random sampling was used in this study to get the number of students in each school category. A formula by Kathuri and Pals (1993) was used to obtain the number of members from each stratum (school type) which was arrived at as follows:

$\mathrm{n}_{i}=\mathrm{N}_{i} / \mathrm{N} * \mathrm{n}$

Where;

$\mathrm{n}_{i}=$ Number of members in the sample from stratum $i$

$\mathrm{N}_{i}=$ Number of members in the population from stratum $i$

$\mathrm{N}=$ Number of members in the entire population

$\mathrm{n}=$ Sample size

$\mathrm{i}=1,2,3$, schools types

Table 1

Samples of students included in the study from different categories of schools

\begin{tabular}{|c|c|c|c|}
\hline School type & $\begin{array}{l}\text { Number } \\
\text { schools }\end{array}$ & $\begin{array}{l}\text { Total Agriculture } \\
\text { students }\end{array}$ & $\begin{array}{l}\text { Sample } \\
\text { size }\end{array}$ \\
\hline Boys' & 2 & 60 & 33 \\
\hline Girls' & 2 & 32 & 18 \\
\hline $\begin{array}{l}\text { Mixed/Co- } \\
\text { educational }\end{array}$ & 13 & 170 & 101 \\
\hline Total & 17 & 262 & \\
\hline
\end{tabular}

A self-administered questionnaire with closed ended items in the Likert scale was used to acquire relevant information from the 152 respondents. The questionnaire collected information on the extent to which information on subject choice was provided, awareness about Agricultural careers and exposure to various teaching methods in Agriculture.

To achieve validity the researcher gave the instrument to two experts from the Department of Agricultural Education and Extension, Faculty of Education and Community Studies of Egerton University. They went through to check the content, face and construct validities, in reference to the study objectives so that each of the specific objectives would be captured in the questionnaire. Improvements were done accordingly. To test the reliability of the instrument, a pilot test was done with 16 students in a school in Kisii Sub-County that was not part of the study area. After piloting, Cronbach's Alpha coefficient was computed to determine reliability of the instrument. A reliability coefficient of 0.78 was observed. This was within the threshold for reliability testing and therefore the instrument was found to be consistent and reliable. The researcher then explained the purpose and the content of the questionnaire then distributed them to respondents in the sampled schools. The respondents were given twenty minutes to fill-in the questionnaires.

The collected data was first cleaned up for any errors then coded and recorded to reduce mass for ease of analysis. Data was then analysed using SPSS version 22. Data on the availability of subject choice information was summarised by use of descriptive statistics (frequencies and percentages). Data on career awareness was measured as an index generated from respondent's rating of five statements, each with a maximum of 5. The maximum score would be 25 implying that the higher the score, the higher the career awareness. This data was analysed using chi-square at $\alpha=0.05$ significance level. Data on teaching methodologies was measured as an index generated from respondents' rating of six statements. The maximum score would be 30 implying that the higher the score the higher the influence and the lower the score the lower the influence. The data was analysed using chi-square at $\alpha=0.05$ significance level.

\section{Results}

Availability of Subject Choice Information: In the study, the researcher sought to find out if the respondents are provided with information on subject choice. Table 2 shows the respondents' frequency distribution according to availability of information on subject choice. 
Table 2

Provision of subject choice information to respondents $(n=152)$

\begin{tabular}{lll}
\hline Option & Frequency & Percent \\
\hline SD & 3 & 2.0 \\
D & 4 & 2.6 \\
U & 1 & .7 \\
A & 78 & 51.3 \\
SA & 66 & 43.4 \\
\hline Total & 152 & 100.0
\end{tabular}

The results show that majority $(94.7 \%)$ of the respondents agreed to having been provided with information on subject choice with $51.3 \%$ and $43.4 \%$ of the respondents in the A and SA categories. A minimal number $(0.7 \%)$ of the respondents were Unaware $(\mathrm{U}) .2 .6 \%$ of the respondents disagreed (D) that they are provided with information on subject choice while $2.0 \%$ strongly disagreed (SD) that they received information on subject choice. The implication of this is that majority of respondents receive information regarding subject choice in their schools. The significance of this information for this study is that availability of information on subject choice may influence decision making when choosing subjects of study.

In this study, sufficiency of subject choice information was operationalised as the climax to show that the information given to respondents is enough to influence their decisions by making them aware during decision making. Table 3 shows the frequency distribution of the respondents according to the sufficiency of subject choice information.

Table 3

Sufficiency of subject choice information $(n=152)$

\begin{tabular}{lll}
\hline Option & Frequency & Percent \\
\hline SD & 6 & 3.9 \\
D & 13 & 8.6 \\
U & 3 & 2.0 \\
A & 66 & 43.8 \\
SA & 63 & 41.7 \\
\hline Total & 152 & 100.0 \\
\hline
\end{tabular}

More than half of the respondents $(84.8 \%)$ said that they receive sufficient subject choice information with $41.4 \%$ SA and $43.4 \%$ A. Only $2.0 \%$ of the respondents were unaware (U). $12.5 \%$ of the respondents said there is not sufficient subject choice information with D (8.6\%) and SD (3.9\%). The implication of this is that majority of the respondents received enough subject choice information. Sufficiency of subject choice information was considered an important aspect of this study because it is important in creating awareness in the respondents when making subject choices since they have several optional subjects to choose from.

\section{Career awareness}

The study sought to find out information on career awareness. This component of career awareness was operationalised and measured using the five statements with a mean maximum score of 5 and minimum score of 1 and sum maximum score of 25 and minimum score of 5 . The mean rating was as shown in Table 4 .

Table 4

Respondents' career awareness

\begin{tabular}{lccc}
\hline Question & Min & Max & Mean \\
\hline $\begin{array}{l}\text { Students receive career } \\
\text { information }\end{array}$ & 1.00 & 5.00 & 4.138 \\
$\begin{array}{l}\text { Have sufficient information } \\
\text { on agriculture occupations }\end{array}$ & 1.00 & 5.00 & 4.157 \\
$\begin{array}{l}\text { Have decided on my } \\
\text { occupational field }\end{array}$ & 1.00 & 5.00 & 4.328 \\
$\begin{array}{l}\text { What I study in agriculture } \\
\text { will be useful in future }\end{array}$ & 1.00 & 5.00 & 4.743 \\
$\begin{array}{l}\text { Career choice important at } \\
\text { present time }\end{array}$ & 1.00 & 5.00 & 4.296 \\
\hline Total & & & $\mathbf{2 1 . 6 6 4}$ \\
\hline
\end{tabular}


A mean of 21.664 implied that there is high level of career awareness among the respondents. This implied that the respondents are greatly informed of available careers at the time of making subject choice.

\section{Agriculture Teachers' Teaching Methods}

The study sought to find descriptive information on the teaching methods by Agriculture teachers. A study by Githaiga (2011) revealed that teachers influenced students on what subjects to take, and also influenced them to take the subjects they teach. It was found out that majority (71.5\%) of the respondents are highly influenced by the teaching methods with and a mean index score of 21.471 out of the possible 30 as shown on Table 5.

Table 5

Influence of teaching methods

\begin{tabular}{lccc}
\hline Question & Min & Max & Mean \\
\hline $\begin{array}{l}\text { Teacher encourages me to } \\
\text { ask questions }\end{array}$ & 1.00 & 5.00 & 4.480 \\
$\begin{array}{l}\text { Teacher is sufficient in } \\
\text { teaching }\end{array}$ & 1.00 & 5.00 & 4.611 \\
$\begin{array}{l}\text { Teacher uses variety of } \\
\text { teaching methods }\end{array}$ & 1.00 & 5.00 & 3.421 \\
$\begin{array}{l}\text { Teacher pays attention to me } \\
\begin{array}{l}\text { Feels fulfilled: teacher } \\
\text { accepts my ideas }\end{array}\end{array}$ & 1.00 & 5.00 & 3.223 \\
$\begin{array}{l}\text { Teacher doesn't put much } \\
\text { pressure on me }\end{array}$ & 1.00 & 5.00 & 3.671 \\
\hline Total & 1.00 & 5.00 & 2.065 \\
\hline
\end{tabular}

\section{Further Information}

The study sought to find out information on dependent variables. The respondents were asked if in their view, they can choose Agriculture in the event that subject choice is done again. They were also asked to indicate if the number of students taking Agriculture in their schools was higher compared to other optional subjects. This information was important because it was used as the indicator of the dependent variable.

Choosing Agriculture Again Given Chance: The study sought to find out from the respondents if they can choose Agriculture subject, if they were given chance again to choose subjects. The results are shown in table 6 .

Table 6

\begin{tabular}{ll} 
Choosing Agriculture again given chance $(n=152)$ \\
& $\begin{array}{l}\text { Given chance to choose } \\
\text { subjects again I will still } \\
\text { choose Agriculture }\end{array}$ \\
\hline $\mathrm{N} \quad$ Valid & 152 \\
Missing & 0 \\
Mean & 4.776 \\
Std. Deviation & .6730 \\
\hline
\end{tabular}

From the results, it is seen that there is an index score of 4.77 out of the possible 5.00 and a standard deviation of 0.67 . These results mean that majority of the respondents will still choose Agriculture subject if they are given another chance to do the choice of subjects. These results could also mean that the respondents did not choose Agriculture subject by mistake but it is a decision they keenly decided to take.

Total of Agriculture Students in Form Three Higher than other Optional Subjects: The respondents were asked to indicate if the proportion of students taking Agriculture in form three is higher compared to other optional subjects. The results are shown in Table 7.

Table 7

Proportion of form three Agriculture students compared with other subjects $(n=152)$

\begin{tabular}{lll}
\hline Option & Frequency & Percent \\
\hline SD & 30 & 19.7 \\
$\mathrm{D}$ & 49 & 32.2 \\
$\mathrm{U}$ & 4 & 2.6 \\
$\mathrm{~A}$ & 19 & 12.5 \\
$\mathrm{SA}$ & 50 & 32.9 \\
\hline Total & 152 & 100.0 \\
\hline
\end{tabular}


The results obtained indicate that less than half (45.4\%) of the respondents indicated that the number of Agriculture students in form three is higher than other optional subjects. More than half (51.9\%) of the respondents indicated that the number of Agriculture students in form three is lower than other optional subjects. This means therefore that the number of Agriculture students in the study area is lower than those who take other optional subjects.

Testing of Study Hypotheses

$H_{01}$ : There is no statistically significant influence of career awareness on the choice of Agriculture subject by secondary school students in Uriri Sub-County.

A Chi-square test was done to determine the influence of career awareness on the choice of Agriculture subject and the null hypothesis tested at $\alpha=0.05$. The results of the Chi-square test are shown in Table 8.

Table 8

\begin{tabular}{llll} 
Influence of career & \multicolumn{3}{c}{ awareness on the choice of Agriculture } \\
\hline & Value & $\mathrm{df}$ & $\begin{array}{l}\text { Asymp. Sig. } \\
\text { (2-sided) }\end{array}$ \\
\hline $\begin{array}{l}\text { Pearson Chi- } \\
\begin{array}{l}\text { Square } \\
\text { Likelihood }\end{array}\end{array}$ & $15.598^{\mathrm{a}}$ & 12 & .210 \\
$\begin{array}{l}\text { Ratio } \\
\text { Linear-by- }\end{array}$ & .821 & 1 & .365 \\
$\begin{array}{l}\text { Linear } \\
\text { Association } \\
\mathrm{N} \text { of Valid } \\
\text { Cases }\end{array}$ & 152 & & \\
\hline
\end{tabular}

a. 13 cells $(65.0 \%)$ have expected count less than 5 . The minimum expected count is .04 .

From the study, there was not enough evidence to indicate that willingness to take Agriculture given another chance is associated with variation in the level of career awareness. This could mean that some students were able to select subjects of study without necessarily relying on career information. While this could have a negative effect on future lives of the students, those students are able to choose subjects on their own without relying on career advice.

$H_{02}$ : There is no statistically significant influence of teaching methods on the choice of Agriculture subject among secondary school students in Uriri Sub-County.-

A chi-square test was carried out to determine the influence of teaching methods on the choice of Agriculture subject. The null hypothesis was tested at $\alpha=0.05$. The results were as shown in Table 9.

Table 9

\begin{tabular}{llll}
\multicolumn{4}{l}{ Influence of teaching methods on the choice of Agriculture } \\
\hline & Value & $\mathrm{df}$ & $\begin{array}{l}\text { Asymp. Sig. } \\
\text { (2-sided) }\end{array}$ \\
\hline $\begin{array}{l}\text { Pearson Chi- } \\
\begin{array}{l}\text { Square } \\
\text { Likelihood Ratio }\end{array}\end{array}$ & $15.810^{\mathrm{a}}$ & 12 & .000 \\
$\begin{array}{l}\text { Linear-by-Linear } \\
\text { Association }\end{array}$ & .171 & 12 & .193 \\
$\mathrm{~N}$ of Valid Cases & 152 & 1 & .679 \\
\hline
\end{tabular}

a. 15 cells $(75.0 \%)$ have expected count less than 5 . The minimum expected count is .02 .

The study suggested that subject choice, indicated by the willingness to choose Agriculture given another chance, is significantly influenced by the teaching methods employed by the Agriculture teacher (Chisquare $=57.81$ ) at a significance level of 0.05 and 12 degrees of freedom. The null hypothesis is rejected. The implication is that students when making subject choices heavily rely on their teachers based on the variety of teaching methods that such teachers employ in the delivery of Agriculture content. The other implication of this is that some Agriculture teachers have made the classroom environment worth learning (Korir, 1996) due to the nature of content delivery hence students just like the teachers and the subjects they teach. Bekleyen (2012), states that some teachers have positive attitudes towards their students and react positively even when students make mistakes.

\section{Conclusions And Recommendation}

Conclusions: From the study, the following conclusions can be drawn:

i. The information on subject choice was available for Agriculture students and is sufficient enough to help them in making decision. 
ii. Teaching methods employed by Agriculture teachers had high influence on the choice to study Agriculture.

iii. Career awareness did not have an influence on the choice of Agriculture.

Recommendations: In order to address the problems students encounter in making subject choice in

Uriri Sub-County and based on the study's conclusions, the following recommendation was made;

i. Teaching methods have high influence on subject choice therefore teachers should employ those methods that make learning of Agriculture motivating.

\section{References}

[1] R. B. Mustapha, \& J.P., Greenan, Role of vocational education in economic development in Malaysia: Educators and employers perspectives. Journal of Industrial Teacher Education. 39 (2), 2007, 10. Retrieved from http://www.exposi tory.org.edu.pdf

[2] W. K. Syeda, Vocational education and skills development: A case of Pakistan, 2010. Retrieved from http://www.finders.edu.au/ed ucation/ie

[3] T. Gazi, (2008). Education in Bangladesh. Retrieved from http://www.siteresources.worldbank.org.html

[4] A. U. Ajidagba, Factors influencing the choice of Islamic studies in the Nigerian secondary schools, doctoral diss., Department of Arts and Social Sciences, University of Ilorin, 2010.

[5] Kenya Institute of Education. Secondary education syllabus, volume two. (Nairobi: KIE, 2002).

[6] F. U. Ngesa, Demand profiles and supply responses for agricultural education and training (AET) at the post-primary level: Case of Kenya. Final report prepared for World Agro-forestry Centre (ICRAF), (Nairobi: ICRAF, 2006).

[7] Kenya National Examinations Council, Regulations for KCSE registration. (Nairobi: KNEC, 2013).

[8] K. L. Hughes, \& M. K. Mechur, School-based career development: A synthesis of the literature. (Columbia University: Institute on Education and the Economy Teachers College, 2004).

[9] J. J. O. Konyango, An analysis of education policies influencing secondary school Agriculture in Kenya and their implications on curriculum improvement between 1959 and 2004, doctoral diss., Egerton University, Njoro, Kenya, 2010).

[10] B. Atweh, S. Taylor, and P. Singh, School curriculum and cultural community in const-ruction of young people's post school aspirations, Australian Association for Research and Education (AARE), 2005). Parramatta: University of Western Sydney. Retrieved from http://www.eprints.qut.edu.au

[11] J. W. Owoyele, \& O.M. Toyobo, Parental will, peer pressure, academic ability and school subject selection by students in senior secondary schools. (Ojebu-ode: Olubade Press, 2008).

[12] D. Bery, Career undecidedness of high school students. Retrieve from http:/advisement.unm.edu/transfer_program/advising\%2520a nd\%2520career\%2520Devpt\%for\%2520Undecided.pdf

[13] A. Bordet, Subject choice in secondary schools, 2002.

[14] A. Wagfield, A. Battle, L. Keller, \& J. Eccles, Sex differences in motivation, self concept, career aspirations and career choice: Implications for cognitive development. (Unpublished)

[15] J. Walkington, Girls selecting Mathematics and Science: Making choices and having expectations. Queensland Journal of Education al Research, 14(1), 2, 1998. Retrieved from http://education.curtin.edu.au/ier/qjer14/walkington.html

[16] F.O. Ohiwerei, \& B.O Nwosu, B. O. Vocational choices among secondary school students: Issues and strategies in Nigeria. Asian Journal of Business Management. 1(2), 2009.

[17] S. Chee, \& P. Leong-Yong, Factors that influence Bruneian students not to enrol in secondary school Agriculture subject. Darusalam: Brunei, 2011).

[18] K. D. Kombo, \& D. L. A. Tromp, Proposal and thesis writing: An introduction. (Nairobi: Paulines Publications Africa, 2006).

[19] O. M. Mugenda, \& A. G. Mugenda, Research methods: Qualitative and quantitative approaches. (Nairobi: ACT Press, 2003).

[20] N. J. Kathuri, \& D. Pals, Introduction to education research. (EMC: Egerton University, Njoro, 1993).

[21] P. N. Githaiga, Factors influencing form two boys and girls choice of KCSE subjects in Kieni Division, Nyeri North District, Kenya, MSc. Project, University of Nairobi, Kenya, 2011).

[22] N. Bekleyen, The influence of teachers and peers on foreign language classroom anxiety.

[23] S. K. Korir, An investigation into the factors contributing to the decline of students' enrolment for Economics in secondary schools in Nakuru District, PGDE Research Project, (Egerton University, Kenya, 1996). 